\title{
Anaerobic bio-digestion of concentrate obtained in the process of ultra filtration of effluents from tilapia processing unit
}

\author{
Milena Alves de Souza ${ }^{1}$, Milena Penteado Chaguri ${ }^{1}$, Fabrício Rogério Castelini ${ }^{2}$, Jorge de \\ Lucas Junior $^{2}$, Rose Meire Vidotti ${ }^{3}$
}

\footnotetext{
1 CAUNESP, Centro de Aquicultura da Unesp, Campus Jaboticabal, São Paulo, Brazil.

2 Faculdade de Ciências Agrárias e Veterinárias da Universidade Estadual Paulista FCAV-UNESP, Campus Jaboticabal, São Paulo, Brazil.

3 Instituto de Pesca - Centro de Pescado Continental, São José do Rio Preto, São Paulo, Brazil.
}

\begin{abstract}
The objective of the present study was to evaluate the efficiency of the process of biodigestion of the protein concentrate resulting from the ultrafiltration of the effluent from a slaughterhouse freezer of Nile tilapia. Bench digesters were used with excrements and water (control) in comparison with a mixture of cattle manure and effluent from the stages of filleting and bleeding of tilapias. The effluent obtained in the continuous process (bleeding + filleting) was the one with highest accumulated population from the $37^{\text {th }}$ day, as well as greatest daily production. Gases composition did not differ between the protein concentrates, but the gas obtained with the use of the effluent from the filleting stage presented highest methane gas average (78.05\%) in comparison with those obtained in the bleeding stage $(69.95 \%)$ and in the continuous process $(70.02 \%)$ or by the control method $(68.59 \%)$.
\end{abstract}

Key Words: biogas, bleeding, filleting, freshwater-fish, methane

\section{Introduction}

In terms of raw materials, water supply and operating unit of fish processing plants vary widely. The processing steps are usually filleting, freezing, drying, fermenting, canning and smoking (Palenzuela-Rollon, 1999). However the generation of effluent on the different plants and forms of processing brings a high organic content, colloidal solutions and particles. Depending on the particular operation, the level of contaminants may be minor, such as during washing; medium, such as in filleting and high, such as at bleeding (Chowdhury et al., 2010).

The processing industries of fish and shellfish often encounter problems with the handling and disposal of waste, due to increased cost of waste treatment plants, particularly with regard to energy.

To deal with such problems and comply with government regulations, the effluent from the fish processing must be treated through a good waste management and treatment technologies (FAO, 1996).

In this context, anaerobic digestion, for having the ability to transform organic materials from agribusiness, livestock and others, in a valuable source of renewable energy as well as reducing odors and other environmental benefits (Prerna \& Singh, 2009), can give not only the reduction in effluent organic materials, but also the generation of the energy needed to meet costs arising from new technologies in the system.

Therefore, the present study aimed to evaluate the production of biogas from anaerobic digestion of concentrate obtained in the process of ultra filtration of effluent from a Nile tilapia refrigerator, using cattle manure for co-digestion.

\section{Material and Methods}

The experiment took place at the salughterhouse freezer Tilápia do Brasil, located in the district of Buritama/SP, which operates with an average of $11,000 \mathrm{~kg}$.fish.day ${ }^{-1}$. The analysis took place at the Aquaculture Centre and at the Department of Rural engineering from the Universidade Estadual Paulista, Jaboticabal/SP campus.

The collection of effluent and ultrafiltration was performed according to the daily operation of the refrigerator, with an average of $2,000 \mathrm{~kg}$ of processed fish. Ultrafiltration proceeded separately from bleeding, filleting and continuous process (bleeding + filleting), hence the three experimental effluents: bleeding; filleting and contiuous process.

The effluent was collected in a box located in the reception area of the slaughter refrigerator, at an amount of 100 liters per effluent, to carry out prior filtration with 
nylon mesh of $500 \mu \mathrm{m}$, to retain larger particles. Later, $10 \%$ of this volume was sent to the ultrafiltration system.

To obtain the proper amount of concentrate for supply of biodigesters, several ultrafiltrations were performed for each effluent until it was possible to obtain 20 liters of concentrate for each process. The concentrate obtained was frozen for further supply the biodigestors.

The ultrafiltration pilot system was constituted by a 12-liter feeding tank, ultrafiltration polysulfone membrane model KOCH, HF 1.0-45-XM50, with a nominal area of $0.09 \mathrm{~m}^{2}$, maximum trans-membrane of $25 \mathrm{psi}$, "cut off" 10.000 at kDa and a centrifugal pump with maximum pressure of $25 \mathrm{psi}$ (Figure 1).

From the filtered volume of the nylon mesh, 10 liters were transferred to the pilot system. The permeate generated was collected in a 20-liter graduate bucket and the final volume for the efficiency rates was written down, as well as the time of each treatment run. The ultrafiltration treatment was interrupted at the moment the permeate flow point was lower than $0.1 \mathrm{~L} \cdot \mathrm{min}^{-1}$.

After each ultrafiltration treatment, the membrane was cleaned with a sodium hydroxide solution ( $\mathrm{pH} 11.0)$, sodium hydroxide + chlorine ( $\mathrm{pH} 11,0+$ chlorine $\left.150 \mathrm{mg} . \mathrm{L}^{-1}\right)$ and acid solution ( $\mathrm{pH} 2$ to 3 ) for a period of 20 minutes. For each process, the concentrate was collected in the amount of 20 liters, for subsequent supply to the biodigestors.

The bench biodigestors were made with PVC pipe and installed within three cement boxes with 500-L capacity, with a volume of water required to prevent loss of gas and maintain the internal temperature of the biodigestors.

Each biodigestor had input inffluent located $5 \mathrm{~cm}$ from the bottom and out of the effluent to $10 \mathrm{~cm}$ below the

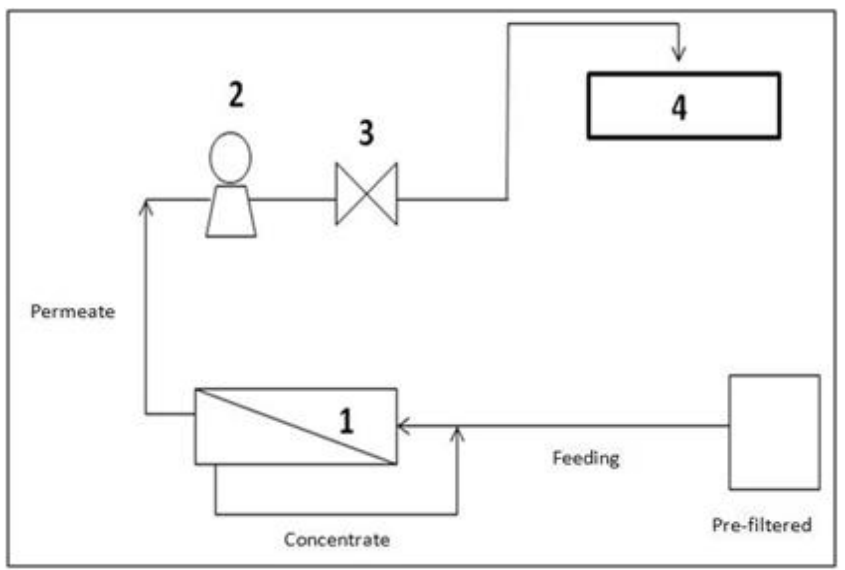

Figure 1 - Schematic of the ultrafiltration pilot system. 1 - ultrafiltration unit; 2 - centrifugal pump; 3 diaphragm valve for flow adjustment; 4 - permeate collection tank. substrate, and internal diameter of $20 \mathrm{~cm}$; the total height was $45 \mathrm{~cm}$ and the working height was $32 \mathrm{~cm}$ (internal diameter/height ratio of 0.625$)$, the charge and discharge pipes of PVC had a diameter of $4 \mathrm{~cm}$ (Figure 2).

The biodigestors had independent gasometers sized to hold $15 \mathrm{~L}$ of biogas, built in reduced scale, whose purpose is to store and allow quantification of the biogas produced by means of a graduated scale affixed to the outside. All gasometers were immersed in a cement box with 1,000 L capacity, containing approximately $750 \mathrm{~L}$ of water and a depth of $5 \mathrm{~mm}$ hydraulic oil so as to maintain the tightness of biogas and prevent the absorption of the $\mathrm{CO}_{2}$ produced.

Each biodigestor was loaded with $7.5 \mathrm{~kg}$ of influent. For processes using concentrates obtained from the ultrafiltration process (bleeding, filleting and continuous process), it was performed along with cattle manure in a 1:1 ratio, which is collected in the Setor de Laticínios of the Universidade Estadual Paulista, mixed with water at a manure:water ratio of 1:5, screened in two different mesh sieves to be later mixed with the concentrate of each process.

For control, biodigestors were filled with $7.5 \mathrm{~kg}$ of mixed waste + water in amounts of $1.5 \mathrm{~kg}$ waste to $7.5 \mathrm{~kg}$ of water; the mixture was sieved according to the procedures performed for other processes, before filling the biodigestors.

For each effluent, three biodigestors were supplied, comprising three repetitions. The quantification of biogas production was done using a graduated scale affixed to the

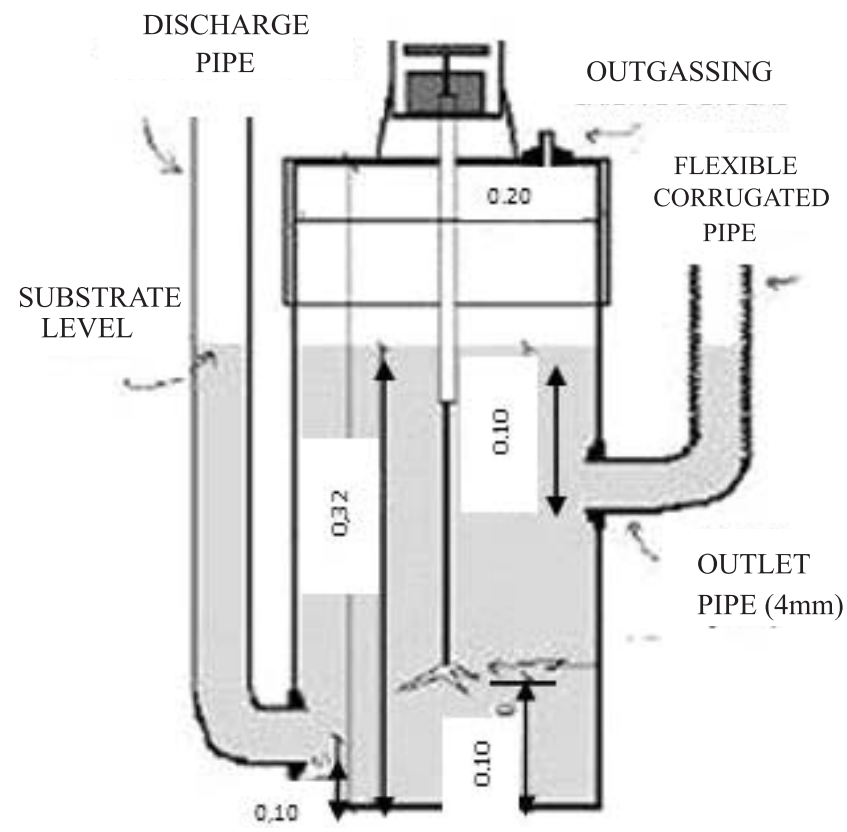

Figure 2 - Details of the biodigestor and cross section. Source: Souza (2001). 
outside of the gasometers, and through the vertical displacement of these it was possible to measure the daily production of biogas.

The volume of biogas was determined by multiplying the height of the displacement of the gas tank area of the internal cross-section $\left(0.30887 \mathrm{~m}^{2}\right)$. After each daily reading, the gasometers were evacuated until they reached the zero. Along with the reading of gas, ambient temperature was measured for subsequent correction of the volume of biogas for $1 \mathrm{~atm}$ and $20^{\circ} \mathrm{C}$ through the expression of a combination of the laws of Boyle and Gay-Lussac:

$$
\frac{V_{0} P_{0}}{T_{0}}=\left(V_{1} P_{1}\right) / T_{1}
$$

where: $\mathrm{V}_{0}=$ volume of biogas corrected, $\mathrm{m}^{3} ; \mathrm{P}_{0}=$ pressure corrected biogas, $10,322.72 \mathrm{~mm} \mathrm{H}_{2} \mathrm{O} ; \mathrm{T}_{0}=$ temperaturecorrected biogas, $293.15 \mathrm{~K} ; \mathrm{V}_{1}=$ volume of gas in the gasometer; $\mathrm{P}_{1}=$ pressure of the biogas at the moment of reading, $9,652.10 \mathrm{~mm}$ de $\mathrm{H}_{2} \mathrm{O} ; \mathrm{T}_{1}=$ temperature of the biogas, $\mathrm{K}$, at the moment of reading.

To assess the composition of the biogas produced, tests were made on the basis of levels of methane $\left(\mathrm{CH}_{4}\right)$, oxygen $\left(\mathrm{O}_{2}\right)$, nitrogen $\left(\mathrm{N}_{2}\right)$ and carbon dioxide $\left(\mathrm{CO}_{2}\right)$. Samples of $50 \mathrm{~mL}$ of each biogas biodigestors were collected weekly throughout the experimental period. Measurements were achieved using gas chromatograph GC 2001 FINNINGAN equipped with columns Porapack Q, Molecular Sieve 5A and a thermal conductivity detector, using hydrogen as carrier gas.

For the influent (Table 1) and effluent of the biodigestors, total nitrogen, total solids, volatile solids (APHA, 1995) and analysis of minerals were analyzed through nitropercloric digestion (APHA, 2000). With the extract obtained from the digestion, it was possible to make the determination of phosphorus $(\mathrm{P})$, potassium $(\mathrm{K})$, calcium
$(\mathrm{Ca})$, magnesium $(\mathrm{Mg})$, sodium $(\mathrm{Na})$, iron $(\mathrm{Fe})$, manganese $(\mathrm{Mn})$, zinc ( $\mathrm{Zn})$ and copper (Cu) (Battaglia, 1983).

The concentrations of $\mathrm{K}, \mathrm{Ca}, \mathrm{Mg}, \mathrm{Na}, \mathrm{Fe}, \mathrm{Mn}, \mathrm{Zn}$ and $\mathrm{Cu}$ were determined in flame atomic absorption spectrophotometer (model GBC $932 \mathrm{AA}$ ).

For the data of accumulated biogas production, the statistical design was entirely developed in split plot with three processes (bleeding, filleting, continuous process) and control, taking the days as subplots with three replications for each plot. For other data the statistical design was entirely developed with four treatments and three repetitions. The averages were submitted to analysis of variance (ANOVA) and compared by Tukey test (5\%).

\section{Results and Discussion}

In the data from the biodigestor effluent (Table 2) there is difference in bleeding and continuous process compared with other concentrates for $\mathrm{K}$, and the control variables differed significantly in $\mathrm{Ca}, \mathrm{Cu}, \mathrm{Fe}$ and $\mathrm{Mg}$, showing no statistical difference for $\mathrm{Cu}$ and $\mathrm{Fe}$ when compared with continuous process and bleeding, respectively.

With regard to reducing the concentration of the variables between the influent and effluent, it was possible to obtain reduction of concentration of all the different protein concentrates studied, with the exception of magnesium, which was improved in all concentrates, due to loss of carbon-rich compounds, such as the case of $\mathrm{CO}_{2}$ and $\mathrm{CH}_{4}$ as well as the high reduction of the total solids (53.87\% bleeding; $70.01 \%$ continuous process; $63.08 \%$ filleting, $75.79 \%$ control) and volatile solids ( $66.81 \%$ bleeding; 77.00 continuous process $\%, 75.74 \%$ filleting; $79.85 \%$ control), indicating extensive removal of organic matter and mineral. According to Yadvika et al. (2004) it is possible to increase

Table 1 - Composition of the inffluent of the biodigestors containing different protein concentrates from bleeding, continuous process, filleting and control

\begin{tabular}{|c|c|c|c|c|}
\hline \multirow[t]{2}{*}{ Variable } & \multicolumn{3}{|c|}{ Origins of protein concentrate } & \multirow[b]{2}{*}{ Control } \\
\hline & Bleeding & Continuous process & Filleting & \\
\hline Total nitrogen $\left(\mathrm{mg} \cdot \mathrm{kg}^{-1}\right)$ & 101.630 & 48.490 & 40.640 & 29.120 \\
\hline Volatile solids $(\%)$ & 0.657 & 0.939 & 0.540 & 0.938 \\
\hline Total solids $(\%)$ & 0.774 & 1.074 & 0.577 & 1.128 \\
\hline Phosphorus (mg.kg-1) & 10.470 & 11.610 & 10.940 & 14.310 \\
\hline Magnesium (mg.kg-1) & 1.048 & 1.048 & 1.096 & 2.241 \\
\hline Potassium (mg.kg-1) & 2.428 & 1.833 & 2.643 & 4.537 \\
\hline Calcium (mg.kg-1) & 2.344 & 2.344 & 2.538 & 4.828 \\
\hline Zinc $\left(\mathrm{mg} \cdot \mathrm{kg}^{-1}\right)$ & 0.037 & 0.053 & 0.040 & 0.039 \\
\hline Manganese (mg.kg-1) & 0.043 & 0.042 & 0.043 & 0.073 \\
\hline Iron $\left(\mathrm{mg} \cdot \mathrm{kg}^{-1}\right)$ & 0.584 & 0.624 & 0.525 & 0.507 \\
\hline Cooper $\left(\mathrm{mg} \cdot \mathrm{kg}^{-1}\right)$ & 0.01 & 0.02 & 0.017 & 0.006 \\
\hline $\mathrm{pH}$ & 6.75 & 6.85 & 6.75 & 6.31 \\
\hline
\end{tabular}


the production of biogas and, consequently, the methane concentration by adding inorganic additives such as calcium and magnesium in anaerobic digesters. In this sense, it is observed in the present study that in the data obtained for the composition of gases (Table 3), the highest concentrations of $\mathrm{CH}_{4}$ accompany the greatest increase in $\mathrm{Mg}$, as is the case of filleting with methane concentration of $78.05 \%$ and greater increase of $\mathrm{Mg}$ with bleeding, $31.25 \%$ and $40.0 \%$, respectively.

For the composition of the gases, there is no statistical difference for $\mathrm{O}_{2}, \mathrm{~N}_{2}$ and $\mathrm{CH}_{4}$ from concentrates, and for $\mathrm{CO}_{2}$, there is difference between continuous process and bleeding when compared with filleting.

The $\mathrm{CH}_{4}$ concentrations studied were all concentrated at higher average commonly found to pig slurry and cattle manure co-digestion. Comino et al. (2009) observed the production of biogas from the co-digestion of manure bovine and whey with 56 days of retention, and obtained value of $51.4 \% \mathrm{CH}_{4}$ in biogas. According to Lansing et al. (2008a), in a study of swine manure and dairy waste, the methane concentrations found for these residues are around $62.6 \%$ and $76.4 \%$, respectively, lower than the values observed for filleting, which is noted for its $78.05 \%$. Stabnikova et al. (2008), dealing with food waste in anaerobic reactors, found average levels of $70 \%$ of this gas. Luna et al. (2009), treating organic waste anaerobic reactor with a low concentration of solids, observed average concentration of $50 \%$ of methane.

Ogejo \& Li (2010) studied the co digestion of waste processing turkey with bovine manure in different proportions $(100,67,50,33$ and $0 \%$ waste). Concentrations of methane were obtained from $56 \%$ to $70 \%$, and increased methane concentrations accompanied the increase in the concentrations of waste added. Data for methane biogas from waste of fish, especially freshwater fish, were not found in the literature.

Comparing the average concentrations of $\mathrm{CH}_{4}$ with the control, there was a greater concentration of this in all concentrates, indicating that the concentrate used is a good substrate for biogas production in co-digestion with bovine manure.

Another important factor to be considered are the $\mathrm{pH}$ values found for the inffluent and the effluent of the biodigestors: between 6.0 to 7.0 for the influent and from 7.0 to 8.0 for the effluent for all concentrates; one of the factors responsible for the high concentration of methane in the biogas produced, corroborating with Mattiason (1998), cited by Yadvika et al. (2009), who states: pH above 5.0 to ensure efficiency in the production of $\mathrm{CH}_{4}$ of about $75 \%$.

Table 2 - Variance analysis for the variables of the biodigestors effluent containing protein concentrates from bleeding; continuous process; filleting and control

\begin{tabular}{|c|c|c|c|c|c|c|}
\hline \multirow[t]{2}{*}{ Variable } & \multicolumn{3}{|c|}{ Origins of protein concentrate } & \multirow[b]{2}{*}{ Control } & \multicolumn{2}{|c|}{ Statistics } \\
\hline & Bleeding & Continuous process & Filleting & & $\mathrm{F}$ & $\mathrm{CV}(\%)$ \\
\hline Total N (mg. $\left.\mathrm{kg}^{-1}\right)$ & $26.820 \mathrm{a}$ & $32.110 \mathrm{a}$ & $28.380 \mathrm{a}$ & $22.640 \mathrm{a}$ & 2.79 & 14.78 \\
\hline Volatile solids $(\%)$ & $0.218 \mathrm{a}$ & $0.216 \mathrm{a}$ & $0.131 \mathrm{a}$ & $0.189 \mathrm{a}$ & 2.51 & 23.44 \\
\hline Total solids (\%) & $0.357 \mathrm{a}$ & $0.322 \mathrm{a}$ & $0.213 \mathrm{a}$ & $0.273 \mathrm{a}$ & 2.83 & 22.13 \\
\hline Phosphorus (mg.kg-1) & $8.020 \mathrm{a}$ & $6.490 \mathrm{a}$ & $6.680 \mathrm{a}$ & $7.880 \mathrm{a}$ & 1.52 & 15.39 \\
\hline Magnesium (mg.kg-1) & $1.748 b$ & $1.199 \mathrm{~b}$ & $1.598 b$ & $2.697 \mathrm{a}$ & 14.73 & 15.37 \\
\hline Potassium (mg.kg-1) & $2.097 \mathrm{~b}$ & $2.097 \mathrm{~b}$ & $1.295 \mathrm{a}$ & $3.187 \mathrm{a}$ & 5.90 & 25.53 \\
\hline Calcium (mg. $\left.\mathrm{kg}^{-1}\right)$ & $1.536 \mathrm{~b}$ & $1.486 \mathrm{~b}$ & $1.396 \mathrm{~b}$ & $2.194 \mathrm{a}$ & 17.19 & 9.53 \\
\hline Zinc (mg. $\left.\mathrm{kg}^{-1}\right)$ & $0.031 \mathrm{a}$ & $0.031 \mathrm{a}$ & $0.025 \mathrm{a}$ & $0.017 \mathrm{a}$ & 3.00 & 25.74 \\
\hline Manganese $\left(\mathrm{mg} \cdot \mathrm{kg}^{-1}\right)$ & $0.014 \mathrm{a}$ & $0.012 \mathrm{a}$ & $0.013 \mathrm{a}$ & $0.016 \mathrm{a}$ & 1.49 & 18.53 \\
\hline Iron $\left(\mathrm{mg} \cdot \mathrm{kg}^{-1}\right)$ & $0.379 \mathrm{a}$ & $0.326 \mathrm{ab}$ & $0.262 \mathrm{ab}$ & $0.165 b$ & 6.33 & 22.26 \\
\hline Cooper (mg.kg-1) & $0.008 \mathrm{ab}$ & $0.016 \mathrm{a}$ & $0.007 \mathrm{ab}$ & $0.001 \mathrm{~b}$ & 5.48 & 57.54 \\
\hline $\mathrm{pH}$ & 7.6 & 7.6 & 7.7 & 7.3 & & \\
\hline
\end{tabular}

Means followed by the same letter do not differ among themselves according to Tukey test (P>0.05); CV - coefficient of variation; F - F value.

Table 3 - Variance analysis for the averages of biogas carbon dioxide, oxygen, nitrogen and methane biodigestors generated by the different protein concentrates and control

\begin{tabular}{|c|c|c|c|c|c|c|}
\hline \multirow[t]{2}{*}{ Varible (\%) } & \multicolumn{3}{|c|}{ Origins of protein concentrate } & \multirow[b]{2}{*}{ Control } & \multicolumn{2}{|c|}{ Statistics } \\
\hline & Bleeding & Continuous process & Filleting & & $\mathrm{F}$ & CV $(\%)$ \\
\hline $\mathrm{CO}_{2}$ & $20.11 \mathrm{a}$ & $21.58 \mathrm{a}$ & $10.64 \mathrm{~b}$ & $16.42 \mathrm{ab}$ & 17.26 & 12.00 \\
\hline $\mathrm{O}_{2}{ }^{2}$ & $0.27 \mathrm{a}$ & $0.24 \mathrm{a}$ & $0.34 \mathrm{a}$ & $0.39 \mathrm{a}$ & 0.30 & 27.12 \\
\hline $\mathrm{N}_{2}^{2}$ & $9.70 \mathrm{a}$ & $8.28 \mathrm{a}$ & $11.16 \mathrm{a}$ & $14.60 \mathrm{a}$ & 10.60 & 30.67 \\
\hline $\mathrm{CH}_{4}$ & $69.95 \mathrm{a}$ & $70.02 \mathrm{a}$ & $78.05 \mathrm{a}$ & $68.59 \mathrm{a}$ & 71.93 & 4.62 \\
\hline
\end{tabular}

Means followed by the same letter do not differ according to the Tukey test $(\mathrm{P}>0.05)$; $\mathrm{CV}$ - coefficient of variation; $\mathrm{F}-\mathrm{F}$ value. 
However, relating the levels of total nitrogen with the concentration of $\mathrm{CH}_{4}$ in the biogas, it is observed that the lower levels of this gas come with the highest levels of total nitrogen and therefore the higher $\mathrm{pH}$ values, thus causing a reduction in methanogenic activity with occurrence of reducing the concentration of $\mathrm{CH}_{4}$ (Lansing et al., 2008b). Therefore, in the residue where effluent has a higher concentration of total nitrogen, $\mathrm{CH}_{4}$ levels were lower, as in the case of bleeding and continuous process, with 101.63 and $48.49 \mathrm{mg} \mathrm{L}^{-1}$ concentrations of total nitrogen and 69,95 and $70.02 \%$ of $\mathrm{CH}_{4}$, respectively, while for filleting, it has a concentration of $40.64 \mathrm{mg} \mathrm{L}^{-1}$ total nitrogen and $78.95 \%$ of $\mathrm{CH}_{4}$.

Same behavior was observed by Salminen \& Rintala (2002) in a study of anaerobic digestion of poultry slaughterhouse waste, where for the highest levels of nitrogen, the lowest production of methane were observed, and in the lower hydraulic retention times studied (25 to 13 days) gas production was interrupted, as indicative of the presence of volatile fatty acids and long chain fatty acids, which can interrupt the process for a certain period, but is reversible over time.

Yadvika et al. (2004) indicate that high levels of nitrogen can affect the performance of anaerobic digesters at high temperatures, affecting the production and composition of biogas. However, the authors report that the addition of nitrogen can increase the production of biogas in the winter. Thus, at low temperature, the substrates evaluated could have higher production than that found in this study, which was performed with an average temperature of $29.59^{\circ} \mathrm{C}$.

In the case of biogas production accumulated over the experimental period (Figure 3 ), it is possible to see higher production and longer digestion for the concentrate in the continuous process as substrate, with statistical difference between the concentrates from the $37^{\text {th }}$ day.

The same occurs in the results obtained for the daily production of biogas (Table 4), with a significant statistical difference when continuous process is compared with filleting and control, with the highest average daily production of biogas for continuous process from concentrates evaluated as $0.0033 \mathrm{~m}^{3}$ biogas. day ${ }^{-1}$.

For potential production of biogas (Table 5), continuous process has the highest average in relation to $\mathrm{m}^{3}$ of biogas per kg of inffluent, $0.0297 \mathrm{~m}^{3} \cdot \mathrm{kg}$.inffluent ${ }^{-1}$, which differs from the control, and filleting, with lower average production found as 0.0087 and $0.0077 \mathrm{~m}^{3} . \mathrm{kg}$.inffluent ${ }^{-1}$, respectively.

The potential production per $\mathrm{kg}$ of inffluent found for bleeding, filleting and control was lower than that found for continuous process, with the potential of $0.0297 \mathrm{~m}^{3} . \mathrm{kg}$ inffluent $^{-1}$, which is consistent with that described by Amaral et al. (2004) for dairy cattle manure with a potential of 0.025 inffluent $\mathrm{m}^{3} \cdot \mathrm{kg}^{-1}$.

In the case of biogas production potential for total solids added, there is statistical difference between control and continuous process, with continuous process

Table 4 - Averages of daily production of biogas $\left(\mathrm{m}^{3}\right)$ corrected to $20^{\circ} \mathrm{C}$ and $1 \mathrm{~atm}$ for different protein concentrates from bleeding; continuous process; filleting and control

\begin{tabular}{cc}
\hline Origins of protein concentrate & $\mathrm{m}^{3}$ biogas.day $^{-1}$ \\
\hline Filleting & $0.0011 \mathrm{~b}$ \\
Bleeding & $0.0021 \mathrm{ab}$ \\
Continuous process & $0.0033 \mathrm{a}$ \\
Control & $0.0010 \mathrm{~b}$ \\
F value & 5.04 \\
Average & 0.0019 \\
CV $(\%)$ & 43.14 \\
\hline
\end{tabular}

Means followed by the same letter in columns do not differ according to Tukey test $(\mathrm{P}>0.05) ; \mathrm{CV}$ - coefficient of variation; F - F value.

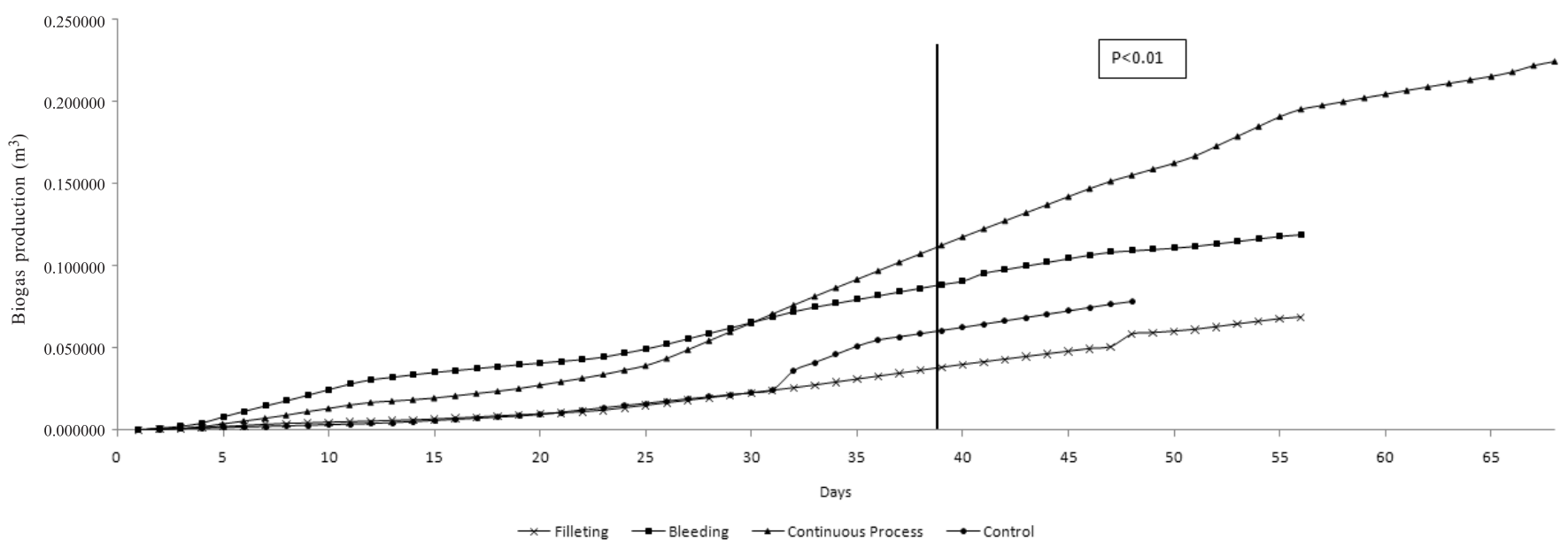

Figure 3 - Cumulative average daily production of biogas, corrected to $20^{\circ} \mathrm{C}$ and $1 \mathrm{~atm}$ for biodigestors filled with a mixture of bovine manure and protein concentrate obtained in the process of ultrafiltration. 
Table 5 - Analysis of variance for the average of the potential biogas production for different protein concentrates from bleeding, continuous process, filleting and control

\begin{tabular}{|c|c|c|c|c|c|c|}
\hline \multirow[t]{2}{*}{ Production } & \multicolumn{3}{|c|}{ Origins of protein concentrate } & \multirow[b]{2}{*}{ Control } & \multicolumn{2}{|c|}{ Statistics } \\
\hline & Filleting & Bleeding & Continuous process & & $\mathrm{F}$ & $\mathrm{CV}(\%)$ \\
\hline $\mathrm{m}^{3}$.biogas & $0.058 b$ & $0.1077 \mathrm{ab}$ & $0.2237 \mathrm{a}$ & $0.0647 \mathrm{~b}$ & 6.29 & 46.64 \\
\hline $\mathrm{m}^{3} \cdot \mathrm{kg}$ inffluent $\mathrm{t}^{-1}$ & $0.0077 \mathrm{~b}$ & $0.0143 \mathrm{ab}$ & $0.0297 \mathrm{a}$ & $0.0087 \mathrm{~b}$ & 6.24 & 46.68 \\
\hline $\mathrm{m}^{3} \cdot \mathrm{kg}$ TS added ${ }^{-1}$ & $1.3367 \mathrm{ab}$ & $1.8700 \mathrm{ab}$ & $2.7327 \mathrm{a}$ & $0.7633 b$ & 4.24 & 42.01 \\
\hline $\mathrm{m}^{3} \cdot \mathrm{kg}$ TS reduced ${ }^{-1}$ & $2.1033 \mathrm{a}$ & $3.7973 \mathrm{a}$ & $3.9097 \mathrm{a}$ & $1.0290 \mathrm{a}$ & 3.64 & 46.63 \\
\hline $\mathrm{m}^{3} \cdot \mathrm{kg}$ VS added ${ }^{-1}$ & $1.5037 \mathrm{a}$ & $2.2083 \mathrm{a}$ & $3.1253 \mathrm{a}$ & $0.9190 \mathrm{a}$ & 3.58 & 44.89 \\
\hline $\mathrm{m}^{3} \cdot \mathrm{kg}$ VS reduced ${ }^{-1}$ & $2.0310 \mathrm{a}$ & $3.4593 \mathrm{a}$ & $4.0670 \mathrm{a}$ & $1.1963 \mathrm{a}$ & 3.08 & 48.14 \\
\hline
\end{tabular}

Means followed by same letter in rows do not differ ( $\mathrm{P}>0.05)$ by Tukey test; CV - coefficient of variation; F - F value; TS - total solids; VS - volatile solids.

presenting the greatest potential among all concentrates: $2.7327 \mathrm{~m}^{3} \cdot \mathrm{kg}$.total solids added ${ }^{-1}$, data higher than those found by Rosenwinkel \& Meyer (1999) for bovine slaughterhouse waste with 17 days hydraulic retention, with a production potential of $0.23 \mathrm{~m}^{3} \cdot \mathrm{kg}$.total solids added ${ }^{-1}$. For the remaining potential of biogas production there are statistical differences between the concentrates.

According to Amaral et al. (2004), the best factor to reflect the potential of biomass is determined to express the potential of biogas production by total solids added. For this purpose, the author evaluated the potential of total solids added per $\mathrm{kg}$ of manure bovine digestion, finding mean values between 0.10 and $0.12 \mathrm{~m}^{3}$ per $\mathrm{kg}$ total solids added, and 0.12 to $0.15 \mathrm{~m}^{3}$ per kg volatile solids added, lower than those found in this study, averaging 1.33, 1.87, 2.73 and $0.76 \mathrm{~m}^{3}$ per $\mathrm{kg}$ total solids added to filleting, bleeding, continuous process and control, respectively. As for manure of goats, the production potential described by Amorim et al. (2004) was on average $0.29 \mathrm{~m}^{3} \cdot \mathrm{kg}^{-1}$; while for pigs, Orrico Junior (2008), using bench biodigestors operated with HRT of 29 days, observed average potential of biogas production of $0.814 \mathrm{~m}^{3} . \mathrm{kg}$ total solids added.

Salminen \& Rintala (2002) studied the anaerobic digestion of poultry slaughterhouse waste production and had average of around 0.52 to $0.55 \mathrm{~m}^{3} . \mathrm{kg}$ volatile solids added data, also lower than those obtained in this study (filleting - 1.5037; bleeding - 2.2083; continuous process 3.1253; control - 0.9190).

The concentrate obtained in the process of ultrafiltration treated in anaerobic digesters provided high potential for biogas production, higher than the values found for waste commonly treated by this technology. Among all concentrates evaluated, the one coming from the continuous process of fish processing gave better results compared with the others. Therefore, the anaerobic digestion can be a solution to guarantee the quality of effluent, as well as for the generation of energy to supply part of the needs of a fish processing unit.

\section{Conclusions}

Among the protein concentrates evaluated, the concentrate obtained from the effluent of the continuous process was the one with the largest potential for biogas production in all the indices evaluated, demonstrating that the effluent coming from the processing of freshwater fish after ultrafiltration may have its protein concentrate treated in anaerobic digesters, ensuring the energy efficiency of the system without the need for separation of the effluent generated in the bleeding and filleting processes.

\section{References}

AMARAL, C.M.C.; AMARAL, L.A.; LUCAS JUNIOR, J. et al. Biodigestão anaeróbia de dejetos de bovinos leiteiros submetidos a diferentes tempos de retenção hidráulica. Ciência Rural, v.34, n.6, p.1897-1902, 2004.

AMERICAN PUBLIC HEALTH ASSOCIATION - APHA. Standard methods for examination water and wastewater. 19.ed. Washington: Arnold \& Greenberg, 1995. 1100p.

AMERICAN PUBLIC HEALTH ASSOCIATION - APHA. Standard methods for examination of water and wastewater. 20.ed. Washington: Arnold \& Greenberg, 2000. $937 \mathrm{p}$.

AMORIM, A.C.; LUCAS JUNIOR, J.; RESENDE, K.T. Biodigestão de dejetos de caprinos obtidos nas diferentes estações do ano. Engenharia Agrícola, v.24, n.1, p.16-24, 2004.

BATAGLIA, O.G.; FURLANI, A.M.C.; TEIXEIRA, J.P.F. et al Métodos de análises químicas de plantas. Campinas: Instituto Agronômico, 1983. 48p. (Boletim Técnico).

CHOWDHURY, P.; VIRARAGHAVAN, T.; SRINIVASAN, A. Biological treatment processes for fish processing wastewater - A review. Bioresource Technology, v.101, p.239-449, 2010.

COMINO, E.; ROSSO, M.; RIGGIO, V. Development of a pilot scale anaerobic digester for biogás production from cow manure and whey mix. Bioresource Technology, v.100, p.5072-5078, 2009.

FOOD AND AGRICULTURE ORGANIZATION - FAO [1996]. Biogás technology: a trainning manual for extension. In: A system approach to biogas technology. Available at: $<$ http://www.fao.org/docrep/008/ae897e/ae897e00.htm> Accessed on: Oct. 15, 2009.

LANSING, S.; VIQUEZ, J.; MARTINEZ, H. et al. Quantifying electricity generation and waste transformations in a low-cost, plug-flow anaerobic system. Ecological Engineering, v.34, p.332-348, 2008a. 
LANSING, S.; BOTERO, R.B.; MARTIN, J.F. et al. Waste treatment and biogas quality in small-scale agricultural digesters. Bioresource Technology, v.99, p.5881-5890, 2008b.

LUNA, M.L.D.; LEITE, V.D.; LOPES, W.S. et al. Tratamento anaeróbio de resíduos orgânicos com baixa concentração de sólidos. Engenharia Agrícola, v.29, n.1, p.113-121, 2009.

MIRANDA, A.P. Suínos em diferentes fases de crescimento alimentados com milho ou sorgo: desempenho, digestibilidade e efeitos na biodigestão anaeróbia. 2009. 123f. Tese (Doutorado em Zootecnia) - Faculdade de Ciências Agrárias e Veterinárias, Universidade Estadual Paulista, Jaboticabal.

OGEJO, J.A.; LI, L. Enhancing biomethane production from flush dairy manure with turkey processing wastewater. Applied Energy, v.87, n.10, p.3171-3177, 2010.

ORRICO JUNIOR, M.A.P. Biodigestão anaeróbia e compostagem de dejetos de suínos, com e sem separação de sólidos. 2008. 95f. Dissertação (Mestrado em Zootecnia) - Faculdade de Ciências Agrárias e Veterinárias, Universidade Estadual Paulista, Jaboticabal.

PALENZUELA-ROLlon, A. Anaerobic digestion of fish processing wastewater with special emphasis on hydrolysis of suspended solids. London: Taylor \& Francis, 1999. 123p.
SALMINEN, E.; RINTALA, J. Semi-continuous anaerobic digestion of solid poultry slaughterhouse waste: effect of hydraulic retention time and loading. Water Research, v.36, p.3157-3182, 2002.

SINGH, S.P.; PRERNA, P. Review of recent advances in anaerobic packed bed biogas reactors. Renewable and Sustainable Energy Reviews, v.13, n.6-7, p.1569-1575, 2009.

SOUZA, C.F. Biodigestão anaeróbia de dejetos de suínos: obtenção de dados e aplicação no desenvolvimento de um modelo dinâmico de simulação da produção de biogás. 2001. $140 \mathrm{f}$. Tese (Doutorado em Zootecnia - Área de Concentração em Produção Animal) - Faculdade de Ciências Agrárias e Veterinárias, Universidade Estadual Paulista, Jaboticabal.

STABNIKOVA, O.; LIU, X.Y.; WANG, J.Y. Anaerobic digestion of food waste in a hybrid anaerobic solid-liquid system with leachate recirculation in an acidogenic reactor. Biochemical Engineering Journal, v.41, n.1, p.198-201, 2008.

YADVIKA, SANTOSH; SREEHRISHNAN, T.R. et al, Enhancement of biogas production from solid substrates using different techiniques - a review. Bioresource Technology, v. 95, p.1-10, 2004. 